\title{
Preliminary Observations About Forage Potential of Chia
}

\author{
Harbans L. Bhardwaj ${ }^{1}$ \\ ${ }^{1}$ Agricultural Research Station, Virginia State University, Petersburg, VA, USA \\ Correspondence: Harbans L. Bhardwaj, Agricultural Research Station, Virginia State University, Petersburg, \\ Virginia 23806, USA. Tel: 1-804-524-6723. Fax: 1-804-524-5950. E-mail: hbhardwaj@vsu.edu
}

Received: May 4, 2021

doi:10.5539/jas.v13n7p32
Accepted: June 1, $2021 \quad$ Online Published: June 15, 2021

URL: https://doi.org/10.5539/jas.v13n7p32

The research was financed by Virginia State University and US Department of Agriculture (NIFA/Evans-Allen Program).

Use of any trade names or vendors does not imply approval to the exclusion of other products or vendors that may also be suitable.

\begin{abstract}
With a view towards expanding the menu of available summer forages, a study was conducted to characterize forage traits of Chia (Salvia hispanica L.). When grown in Virginia (mid-Atlantic region of the United States) during 2019 and 2020, 60-day old whole vegetative plants of both black-seeded and white-seeded Chia contained approximately 21 percent protein, 1.5 percent potassium, 2.06 percent calcium, 2.4 percent crude fat, 21.2 percent ADF, and 29.4 percent NDF. The fresh and dry biomass yields were 8310 and $814 \mathrm{~kg} \mathrm{ha}^{-1}$, respectively. Based on forage quality values of Chia produced in other countries and other forages, it was concluded that Chia is a potential forage crop.
\end{abstract}

Keywords: Salvia hispanica, forages, protein concentration, oil concentration, ADF, NDF, minerals, alternate crops

\section{Introduction}

Producers can often more fully utilize their labor, land, water, and growing resources by planting a miscellaneous forage. The normal production of cool-season forages shows rapid spring growth, a drop in July and August with some renewed growth in October. There is a need for feed in the heat of summer and during the winter. Annual crops can be produced to provide nutritional feed during these times. Although extending the grazing season may be the priority, many miscellaneous forages are very nutritious (Anonymous, 2021). Miscellaneous forages can be wisely used in a yearly feeding plan.

We postulated that Chia (Salvia hispanica L.) has potential as a forage crop given that it should be suitable due to its' short day length flowering response which should delay its flowering and help in producing and maintaining desirable vegetative growth. Chia is a short-day plant; however, some reports indicate existence of long-day Chia germplasm (Caruso et al., 2018; Sosa-Baldivia et al., 2018).

Salvia hispanica L., commonly known as Chia, Spanish sage or Mexican Salbia, belongs to the genus Salvia of the Lamiaceae family. Chia originated at the low latitudes of Mexico and Guatemala, along with amaranths, quinoa and maize it was one of the four staple foods of Mayas and Aztec populations. The history of Chia as a domesticated crop presents many contradictions. Almost 4,500 years ago in Mesoamerica, Chia was used as food and medicine. However, just only in three centuries, Chia became a forgotten crop and remained an unknown crop for many years (Sosa-Baldivia et al., 2018). The Chia crop was rescued thanks to a small group of farmers in Jalisco, Guerrero, and Puebla. Around 1990, they developed a crop of Chia and preserved the tradition of their use. Today its value as crop and food is so high and their cultivation and consumption are currently taking place in 30 countries. It is asserted that after 500 years of lethargy Chia will be the Sleeping Beauty of Mexico (Sosa-Baldivia et al., 2018).

Chia is an ancient crop from Central America, which has been recently rediscovered as a source of $\omega-3$ and nutraceuticals in seeds. Chia is an annual plant species from the Lamiaceae family that has become very popular 
in the diet of the western world. It was one of the most widely used cultural plants in the pre-Columbian America (Cahill, 2003) and re-gained attention in the last decade of the twentieth century.

The composition of the leaves of Salvia hispanica L. has been the object of few studies. Ahmed et al. (1994) studied leaf oil and its composition from leaves and found 52 compounds. They identified 42 of the chemical components and found that oil composition was dominated by $\beta$-caryophyllene, globulol, $\gamma$-murolene, $\beta$-pinene, $\alpha$-humulene, germacrene- $\mathrm{B}$, and widdrol, but the relative amounts varied as a function of geographical area where the plant was grown, ranging from California to Texas to Argentina. Besides traditional seed consumption, innovative uses of the plant seeds and leaves have been proposed based on the high protein content and the production of mucilage that lends itself to a range of applications (Bochicchio et al., 2015).

Recently research conducted in Basilicata, Southern Italy (Amato et al., 2015), has shown secondary metabolites in leaves and provides the first report of flavonoids in Chia leaves, including two uncommon compounds: acetyl vitexin and acetyl orientin which had never been reported before in the Lamiaceae family. These observations imply potential of Chia as a forage.

Our objectives were to characterize field production of Chia in mid-Atlantic region of the United States of America and to determine its' forage traits. We were not aware of any studies related to characterization of Chia's potential as a forage crop in this area.

\section{Methods}

\subsection{Plant Materials}

The plant material for this study consisted of two Chia types: white-seeded and black-seeded which were purchased from an online source.

\subsection{Production}

Two field experiments, with two types of Chia, were conducted by planting on July 16, 2019 and July 27, 2020 at Randolph Farm of Virginia State University located in Ettrick, VA (lat. $37^{\circ} 15^{\prime} \mathrm{N}$, long. $77^{\circ} 31^{\prime} \mathrm{W}$ ) on Abel sandy loam (Fine Loamy mixed thermic Aquatic Hapridult) soil. Each experiment was planted as an RCBD (Randomized Complete Block Design) with two replications using $3 \mathrm{~m}$ long four-row plots with $1 \mathrm{~m}$ row pacing. Approximately $5 \mathrm{~g}$ seed was planted in each 4-row plot. Upon stand establishment, $100 \mathrm{~kg} \mathrm{ha}^{-1}$ of a 10-10-10 (NPK) fertilizer was applied to these plots. These plots were kept weed free manually and no chemical treatments were applied.

\subsection{Data Recording and Analysis}

One sample ( $1 \mathrm{~m}$ row length from one of the middle rows) was harvested from each plot for data collection. Samples of biomass were collected approximately 60 days after planting. Fresh and dry weights were recorded in grams and then converted to $\mathrm{kg} \mathrm{ha}^{-1}$ for all plots. Concentrations of ADF, NDF, N, B, P, K, Ca, Cu, Fe, Mg, Mn, $\mathrm{Na}, \mathrm{S}$, and $\mathrm{Zn}$ were determined, using AOAC methods (AOAC, 2016) by Waypoint Analytical Laboratory (Richmond, Virginia, USA). Total protein concentration was estimated by multiplying $\mathrm{N}$ content with protein factor 6.25 .

All data were analyzed using version 9.1 of SAS (SAS Institute, Inc., 2014) using ANOVA with 5\% level of significance. Composition traits of Chia plant tissue were compared to literature values for buckwheat, alfalfa hay, perennial peanut, soybean forage, and Tepary bean.

\section{Results and Discussion}

Results (Table 1) indicated that black-seeded Chia had significantly higher fresh (a differential of approximately 16 percent) and dry (a differential of about 12 percent) biomass yields. Black-seeded Chia biomass had significantly higher ADF, boron, and iron (23.8 and 18.6 percent, 32 and $24 \mathrm{mg} / \mathrm{kg}$, and 475 and $313 \mathrm{mg} / \mathrm{kg}$, respectively) whereas white-seeded Chia biomass had significantly higher phosphorus and manganese ( 0.36 and 0.32 percent, 94.5 and $64.0 \mathrm{mg} / \mathrm{kg}$, respectively). Concentrations of crude fat, crude protein, NDF, potassium, calcium, magnesium, sulfur, sodium, zinc, copper, and aluminum were not different in black-seeded and white-seeded Chia biomass. 
Table 1. Traits of 60-day old black-seeded and white-seeded Chia whole plant tissue grown during 2019 and 2020 at Ettrick, Virginia (USA)

\begin{tabular}{|c|c|c|c|c|}
\hline \multirow{2}{*}{ Trait } & \multicolumn{2}{|c|}{ Chia types $^{1}$} & \multicolumn{2}{|c|}{ Year of production ${ }^{2}$} \\
\hline & White-seeded & Black-seeded & 2019 & 2020 \\
\hline Fresh yield $\left(\mathrm{kg} \mathrm{ha}^{-1}\right)$ & 7702 & $8917 *$ & $8587 \mathrm{a}$ & $8052 a$ \\
\hline Dry yield $\left(\mathrm{kg} \mathrm{ha}^{-1}\right)$ & 755 & $874 *$ & $842 a$ & $787 \mathrm{a}$ \\
\hline Fat $^{\mathrm{a}}$ & 2.64 & 2.24 & 2.69 & 2.20 \\
\hline Protein $^{\mathrm{a}}$ & 21.1 & 21.4 & 25.2 & $17.3 * * *$ \\
\hline $\mathrm{ADF}^{\mathrm{a}}$ & 18.6 & $23.8^{*}$ & 26.2 & $16.2^{* * *}$ \\
\hline $\mathrm{NDF}^{\mathrm{a}}$ & 27.2 & 31.4 & 33.4 & $25.3 * *$ \\
\hline $\mathrm{P}^{\mathrm{a}}$ & 0.36 & $0.32 *$ & 0.36 & 0.32 \\
\hline $\mathrm{K}^{\mathrm{a}}$ & 1.38 & 1.56 & 2.11 & $0.83 * * *$ \\
\hline $\mathrm{Ca}^{\mathrm{a}}$ & 2.10 & 2.03 & 1.78 & $2.35 * * *$ \\
\hline $\mathrm{Mg}^{\mathrm{a}}$ & 1.04 & 1.11 & 1.01 & $1.14 *$ \\
\hline $\mathrm{S}^{\mathrm{a}}$ & 0.32 & 0.30 & 0.31 & 0.31 \\
\hline $\mathrm{Na}^{\mathrm{b}}$ & 0.15 & 0.15 & 0.01 & $0.02 * * *$ \\
\hline $\mathrm{B}^{\mathrm{b}}$ & 24.2 & $32.0 * *$ & 32.5 & $24.0 * *$ \\
\hline $\mathrm{Zn}^{\mathrm{b}}$ & 41.7 & 46.5 & 36.0 & $52.2 *$ \\
\hline $\mathrm{Mn}^{\mathrm{b}}$ & 94.5 & $64.0 * *$ & 77.7 & 80.7 \\
\hline $\mathrm{Fe}^{\mathrm{b}}$ & 313 & $475^{* * *}$ & 484 & $324 * *$ \\
\hline $\mathrm{Cu}^{\mathrm{b}}$ & 10.7 & 10.5 & 10.7 & 10.5 \\
\hline $\mathrm{Al}^{\mathrm{b}}$ & 213 & 335 & 38 & $190 *$ \\
\hline
\end{tabular}

Note. ${ }^{1}$ : Means based on two production years; ${ }^{2}:$ Means based on two Chia types.

a: Percentage values on dry weight basis; $b$ : Values as parts per million.

$*, * *$, and $* * *$ : Means were significantly different at 10,5, and 1 percent levels, respectively.

Production years exhibited significant effects on most biomass traits of Chia. Biomass produced during 2019 was superior to that produced during 2020 for crude protein, ADF, NDF, potassium, boron, iron, and aluminum whereas biomass produced during 2020 was superior that that produced during 2019 for concentrations of calcium, magnesium, sodium, and zinc. Year of production effects on fresh and dry biomass yields, crude fat, phosphorus, sulfur, manganese, and copper were not significant.

Whole plant biomass yield of Chia has been reported to vary from 492 to $3675 \mathrm{~kg} \mathrm{ha}^{-1}$ from northwestern Argentina, Ghana, Greece, northern Chile, and southern Italy. Jamshidi et al. (2019) observed lack of published works on the use of Chia herbage in animal nutrition, however forage use of Chia vegetative parts was suggested by Peiretti and Gai (2009), who determined a whole panel of chemical analyses relevant for animal nutrition. According to these authors Chia plant biomass is a good source of polyunsaturated fatty acids (with ALA proportion varying between 649 and $565 \mathrm{~g} / \mathrm{kg}$ total FA between early and late vegetative stage). The stage before shooting is the best time for harvesting forage with a good nutritive value. The protein content has varied between $188(\mathrm{~g} / \mathrm{kg}$ DM basis) at early vegetative stage and $122(\mathrm{~g} / \mathrm{kg} \mathrm{DM})$ at late vegetative stage to fall at 76 $(\mathrm{g} / \mathrm{kg} \mathrm{DM})$ during shoot stage. Forage quality of Chia vegetative plants has been observed to change with growth stage from early vegetative stage to plant budding with an increase in fibrous fractions (acid and neutral detergent fiber and lignin) and gross energy and a decrease in fats and ashes. Another study (Peiretti, 2010) suggested that Chia whole plant harvested at the budding stage has a good potential for large scale ensiling.

Bilalis et al. (2016) conducted an agronomic trial and found that fertilizing with manure affects crude protein and both acid and neutral-detergent fiber. This study revealed that Chia growth was not affected by sowing rates and fertilization, there were no significant differences for dry weight and leaf area index (LAI) among fertilization treatments, sowing rates influenced both dry and LAI which were significantly increased as sowing rates increased, forage quality traits were not significantly influenced by sowing rates, fertilization treatments had a positive influence on crude protein concentration, and acid detergent fiber (ADF) as well as neutral detergent fiber (NDF) were not affected by sowing rates. These data suggest that Chia could be successfully used as an alternative forage crop. 
Rossi et al. (2020) reported that Chia total plant yield varied from 5.64 to $9.0 \mathrm{t} / \mathrm{ha}$ during 2013 and 2014 when grown in Italy and crude protein varied from 18 to 8 percent from early vegetative and early flowering stages, respectively. These authors suggested that Chia has potential as a forage crop.

Based on our results related to mean fresh and dry whole plant of Chia, grown in Virginia (lat. $37^{\circ} 15^{\prime} \mathrm{N}$, long. $77^{\circ} 31^{\prime} \mathrm{W}$ ), compared well with other reports and were impressive. Crude protein in Chia produced in Virginia varied from 17 to 21 percent and compared well with literature values of alfalfa hay (19 percent, Meyer et al., 2010), perennial peanut (14 percent, Meyer et al., 2010), soybean forage (19.8 percent, Lundry et al., 2008), and those of Chia reported to vary from 8 to 18 percent by Rossi et al. (2020) from Italy.

Even though black-seed Chia produced significantly greater fresh and dry matter biomass, mean performance over both types of Chia seemed suitable for production in mid-Atlantic region of US. Similarly, performance of Chia over 2019 and 2020, production years being random effects and not controllable, indicates that Chia may be suitable for production during most seasons.

Most Chia cultivars available are short-day and availability of Chia seed for planting could be a challenge. However, both black and white Chia seeds are available online for about $\$ 1.60$ per pound for black-seeded and for about $\$ 2.30$ per pound for white-seeded Chia. Based on our extensive research with canola, we expect that 2-3 pounds seed of per acre Chia would be needed for planting as a forage.

\section{Conclusions}

Results of our preliminary study indicate that Chia is a potential forage crop for middle to northern areas of the US.

\section{References}

Anonymous. (2021). Discuss the importance of utilizing forages other than common grasses and legumes. Retrieved January 4, 2021, from https://forages.oregonstate.edu/nfgc/eo/onlineforagecurriculum/instruct ormaterials/availabletopics/miscellaneous/importance\#: : :text=They\%20are\%20used $\% 20$ to $\% 20$ extend,by\% 20planting\%20a\%20miscellaneous\%20forage

AOAC (Association of Official Analytical Chemists). (2016). Official Methods of Analysis (20th ed.). AOAC, Arlington, VA. Retrieved from http://www.aoac.org/aoac_prod_imis/AOAC/AOAC_Member/PUBSCF/ OMACF/OMAP_M.aspx

Bilalis, D., Tabaxi, I., Zervas, G., Tsiplakou, E., Travlos, I. S., Kakabouki, I., \& Tsioros, S. (2016). Chia (Salvia hispanica) fodder yield and quality as affected by sowing rates and organic fertilization. Commun. Soil Sci. Plant. Anal., 47, 1764-70. https://doi.org/10.1080/00103624.2016.1206921

Bochicchio, R., Philips, T. D., Lovelli, S., Labella, R., Galgano, F., Di Marisco, A., ... Amato, M. (2015). Innovative Crop Productions for Healthy Food: The Case of Chia (Salvia hispanica L.). In A. Vastola (Eds.), The Sustainability of Agro-Food and Natural Resource Systems in the Mediterranean Basin. Springer, Cham. https://doi.org/10.1007/978-3-319-16357-4_3

Cahill, J. P. (2003). Ethnobotany of Chia, Salvia hispanica L. (Lamiaceae). Econ Bot., 57(4), 604-618. https://doi.org/10.1663/0013-0001(2003)057[0604:EOCSHL]2.0.CO;2

Caruso, M. C., Favati, F., Di Cairano, M., Galgano, F., Labella, R., Scarpa, T., \& Condelli, N. (2018). Shelf-life evaluation and nutraceutical properties of Chia seeds from a recent long-day flowering genotype cultivated in Mediterranean area. Food Science and Technology, 87, 400-405. https://doi.org/10.1016/j.lwt.2017. 09.015

Dal Bosco, A., Castellini, C., Martino, M., Mattioli, S., Marconi, O., Sileoni, V., ... Benincasa, P. (2015). The effect of dietary alfalfa and flax sprouts on rabbit meat antioxidant content, lipid oxidation and fatty acid composition. Meat. Sci., 106, 31-37. https://doi.org/10.1016/j.meatsci.2015.03.021

Jamshidi, A. M., Amato, M., Ahmadi, A., Bochicchio, R., \& Rossi, R. (2019). Chia (Salvia hispanica L.) as a novel forage and feed source: A review. Italian Journal of Agronomy, 14, 1297. https://doi.org/ 10.4081/ija.2019.1297

Lundry, D. R., Ridley, W. P., Meyer, J. J., Riordan, S. J., Nemeth, M. A., Trujillo, W. A., ... Sorbet, R. (2008). Composition of grain, forage, and processed fractions from second-generation glyphosate-tolerant soybean, MON 89788, is equivalent to that of conventional soybean (Glycine max L.). J. Agric. Food Chem., 56, 4611-4622. https://doi.org/10.1021/jf073087h 
Meyer, R., Warren, L., Eckert, J., Hancock, D., Blount, A., \& Olson, C. (2010). Perennial peanut: Forage nutritional composition and feeding value. Animal Science Department, Florida Cooperative Extension Service, Institute of Food and Agricultural Sciences, University of Florida, USA. Retrieved from http://edis.ifas.ufl.edu

Peiretti, P. G. (2010). Ensilability characteristics of Chia (Salvia hispanica L.) during its growth cycle and fermentation pattern of its silages affected by wilting degrees. Cub. J. Agric. Sci., 44, 33-36. Retrieved from http://cjascience.com/index.php/CJAS/article/view/288

Peiretti, P. G., \& Gai, F. (2009). Fatty acid and nutritive quality of Chia (Salvia hispanica L.) seeds and plant during growth. Anim. Feed Sci. Technol., 148, 267-75. https://doi.org/10.1016/j.anifeedsci.2008.04.006

Rossi, R., Bochicchio, R., Labella, R., Bitella, G., \& Amato, M. (2020). Fodder yield, quality and growth of Chia (Salvia hispanica L.) as affected by sowing density and top-dressing nitrogen fertilization. Agronomy, 10, 1-23. https://doi.org/10.3390/agronomy 10121980

SAS Institute, Inc. (2014). SAS for Windows version 9.4. SAS Institute, Cary, NC. Retrieved from http://www.sas.com/en_us/software/sas9.html

Sosa-Baldivia, A., Ruiz-Ibarra, G., de la Torres, R. R. R., Lopez, R. R., \& Lopez, A. M. (2018). The Chia (Salvia hispanica): Past, present and future of an ancient Mexican crop. Australian Journal of Crop Science, 12(10), 1626-1632. https://doi.org/10.21475/ajcs.18.12.10.p1202

\section{Copyrights}

Copyright for this article is retained by the author(s), with first publication rights granted to the journal.

This is an open-access article distributed under the terms and conditions of the Creative Commons Attribution license (http://creativecommons.org/licenses/by/4.0/). 